\title{
A Revista Em Construção: arquivos de epistemologia histórica e estudos de ciências um ano após o primeiro número
}

O presente editorial surge da necessidade de um balanço do trabalho realizado pelos editores e colaboradores nos seus três primeiros números, e esclarecimentos sobre o futuro da presente publicação. Aproveitamos o ensejo para agradecer a participação de todo o corpo editorial, conselho científico e todos aqueles que nos últimos doze meses nos ajudaram a construir uma revista acadêmica que tem por princípio norteador a sua intenção de ser lida por todo e qualquer. Como afirmamos no editorial de apresentação, a Em Construção "pretende ser um veículo de formação e de ação cultural e social. Isso porque, e de acordo com a epistemologia histórica e com os science studies, a ciência deve ser entendida à luz de suas interações constituintes com a sociedade, a cultura e a sua própria história. A desconsideração das relações entre a ciência e estas, torna a primeira pálida e desinteressante".

Desde a escrita do projeto da revista, entre fins de 2015 e o início de 2016, até o presente momento passamos por diversos momentos críticos tanto para a pesquisa quanto para o ensino superior no Brasil. Vivemos em tempos instáveis, no mínimo, que não nos permitem esperar por dias melhores ou viver sem esperança e planos a longo prazo. É preciso ter ainda mais firmeza moral e um quê de utopia para ultrapassarmos os obstáculos e reveses, sobretudo políticos, que ora se impõem para o meio acadêmico em âmbito local e nacional. Produzir uma revista acadêmica semestralmente é hoje um desafio para todos os que se dedicam à edição. Por isso, ressaltamos que o trabalho realizado até aqui é resultado do esforço de um grupo de pesquisadores membros do grupo de Estudos Sociais e Conceituais de Ciência, Tecnologia e Sociedade (http://dgp.cnpq.br/dgp/espelhogrupo/5456211078283244) que resistem.

A Universidade, como afirmamos em nosso segundo número - dossiê Universidade e Utilidade, organizado pelo professor Juan Queijo -, deve ser um projeto defendido para e pela sociedade com vistas à produção de conhecimento de excelência. Esse plano passa pela formação de pessoas dedicadas ao tripé: ensino, pesquisa e extensão. A viabilidade e o desenvolvimento profícuo desse projeto dependem tanto de políticas públicas e investimentos do Estado, quanto do compromisso dos envolvidos em suas atividades. Em outros termos, não há Universidade pública e de qualidade sem que Estado e sociedade a vejam como um fim em si, isto é, sem qualquer outra finalidade utilitária.

A despeito das vicissitudes, é com imenso contentamento que publicamos o terceiro número da Revista Em Construção: arquivos de epistemologia histórica e estudos de ciências com o dossiê temático sobre Derrida e as Ciências, organizado pelo professor Fernando Fragozo. Este número será lançado no mês de junho 
devido a alterações no calendário acadêmico da UERJ e as necessárias mudanças observadas nesse primeiro ano de edição. Entendemos, por isso, que as próximas edições devem seguir a atual. Deste modo, teremos dois números anuais, um no final do primeiro semestre e outro ao final do segundo semestre de cada ano.

O quarto número da revista tem por tema "Crise", e será organizado pelo professor Leonardo Miguel; receberemos trabalhos para este dossiê até julho de 2018 pelo site da revista. Para o ano de 2019, apresentaremos um dossiê temático no primeiro semestre: "Gênero e Conhecimento: Saberes localizados e poder" organizado por Rebeca Furtado e Maria Helena Soares, com recebimento de trabalhos até novembro de 2018. A revista também aceita trabalhos de temática livre em fluxo contínuo.

Agradecemos, uma vez mais, aos editores, autores, pareceristas, colaboradores em geral e leitores por apoiarem esta ideia. Sigamos, Em Construção.

Editores da Revista Em Construção. 